\title{
Færøsk før, nu og i fremtiden
}

\section{Av Zakaris Svabo Hansen}

\author{
Länk till presentation av Zakaris Svabo Hansen
}

I denne tekst vil jeg først kort skitsere den historiske baggrund, som færøsk sprogrøgt og sprogpolitik bør forstås i. Dernæst vil jeg gøre nogle punktnedslag i udviklingen i færøsk sprogrøgt op til vore dage og så afslutningsvis komme med nogle vurderinger om fremtidsudsigterne for færøsk sprog.

Det antages, at Færøernes nordiske kolonisation startede omkring år 800, og selv om der er spor af keltisk islæt i sproget, blev det den nordiske bosættelse, der fik varig betydning, også i sproglig henseende på Færøerne. I de følgende århundreder har norrønt været øernes talesprog såvel som lov- og administrationssprog, og øerne må i det hele taget anses for at have været en del af den norrøne kulturkreds.

Men i senmiddelalderen svækkes dette norrøne fællesskab og norrønt mister efterhånden sin rolle som administrationssprog, og med reformationen kan denne svækkelse siges at være fuldbyrdet. Med reformationen overtog de enkelte landes nationalsprog den rolle, som latin forud havde haft som kirkesprog. Dette skete imidlertid ikke på Færøerne lige så lidt som det fx skete i Norge. På Færøerne overtog dansk positionen som lovsprog, retssprog og kirkesprog. Med rette kan det siges, at dansk overtog positionen som standardsproget i landet, og at der samtidig skete en dialektisering af færøsk. Det gamle lovsprog bliver mere og mere uforståeligt, og lovene må oversættes til dansk. Med reformationen holder dansk bibel og salmebog, og dermed vel også dansk prædiken, sit indtog i den færøske kirke. Befolkningens talesprog forblev dog færøsk. Færøerne udviklede sig til at være et tosproget samfund. Modersmålet har tjent som det daglige talesprog og bærer af en mundtlig digttradition (kvadtraditionen), men i sin omgang med myndighederne (embedsmænd og præster eksempelvis) har befolkningen været nødt til at betjene sig af en form for dansk eller en eller anden form for dansk-færøsk blandingssprog.

Da færøsk således ikke eksisterede som officielt sprog og ikke havde nogen skriftnorm, kan det ikke undre, at det heller ikke fandtes nogen form for standardudtale. Talesproget udviklede en række dialekter, og da man omkring 1800 for alvor begynder at føre sproget i pennen igen, først og fremmest ved optegnelse af balladetekster, sætter dette sit præg på teksternes ortografi. Da man ingen fælles retskrivning havde, benyttede hver optegner sig af en mere eller mindre ortofon retskrivning, som derved kommer til at afspejle vedkommendes dialektale baggrund. Det er først i 1846 at det afgørende skridt til en fælles skriftnorm, som relativt hurtigt finder sin endelige form, bliver taget. Hovedmanden bag dette er præsten V.U. Hammershaimb. Denne skriftnorm er etymologisk baseret, dvs. den bygger meget på ældre sprogtrin, men samtidig medfører det at den på en måde forener alle de forskellige dialekter, idet den er superdialektal og ikke favoriserer nogen bestemt dialekt. Det var nok skriftnormens fordel og styrke. Derimod gjorde skriftnormens etymologiske tilsnit, at der opstod en ret stor kløft mellem selve skriftbilledet og udtalen.

Sammenfattende kan det siges, at skriftsproget i aktiv brug således er godt og vel 100 år gammelt, mens selve retskrivningen som nævnt er lidt ældre, ca. 150 år.

Lige fra begyndelsen har ordforrådet stået meget centralt i diskussionen om det færøske skriftsprog. Omkring 100 år inden skriftsproget fik en nogenlunde fast form — dvs. i anden halvdel at 1700-tallet - fortæller oplysningemanden og sprogforskeren J.C. Svabo, at det færøske sprog er ved at uddø af fremmed og i særdeleshed af dansk indflydelse. Det ser ud 
til, at hans ord ikke kun har været tom retorik, fordi da vi kommer frem til slutningen af 1800-tallet, dvs. da færinger igen er begyndt at skrive færøsk, dukker de samme holdninger op igen.

Skriftsproget blev kun lidt anvendt i begyndelsen; det havde ikke stor udbredelse, men blev mest benyttet til spredte folkloristiske optegnelser. Men i 1890 begyndte en færøsksproget avis »Føringatíðindi« at udkomme og den fik stor betydning som formidler af færøsk skriftsprog. Man ser i avisen, at det her med fremmede ord kontra hjemlige ord var en hård nød at knække for dem, der ville skrive færøsk. Naturligt nok fordi færøsk efter en tilværelse som almuesprog var rigt på ordforråd for konkrete ting og sager, men derimod i vid udstrækning savnede ord for mere abstrakte ting. I »Føringatíðindi« ser man eksempler på både fremmede ord (dvs. i praksis ofte sige danske ord) og nyord.

Den første færøske sprogfornyer — eller sprogrenser om vi vil — var dr. Jakob Jakobsen (1864-1918). Han siger således i artiklen »Lidt om sproget og retskrivningen « (1901): »Det færøske sprog er for øjeblikket i en stærk gæringsperiode. På den ene side vrimler det i den daglige tale af ufærøske, navnlig danske, ord og vendinger, så man skulde tro, at sproget med stærke skridt gik sin opløsning i møde; på den anden side er det dog ikke blot muligt, men let overkommeligt i skrift at fremstille et forholdsvis rent færøsk med undgåelse af de fleste i samtalesproget gængse fremmedord. Disse have nemlig som regel ikke (i al fald kun delvis) fortrængt de tilsvarende færøske ord; de bruges i almindelighed side om side med de sidste, ofte ganske i flæng « (Jakob Jakobsen 1957: 48). Jakob Jakobsen siger, at det i særdeleshed er ord for abstrakte fænomener, som er indkommet i sproget. Jakobsen mener, at man bør bestræbe sig på at danne nye færøske ord for de fremmede og ellers dyrke gammelt færøsk ordstof som endnu er levende, skønt det kan være meget sjældent i brug.

Senere bliver Jakobsen mere radikal purist. Denne drejning har man sat i forbindelse med hans rejser til Shetland, hvor han optegnede resterne af det gamle nordiske sprog dér. Måske er han på disse rejser blevet bevidst om, at det kunne gå færøsk på samme måde som det gik for norn på Shetland. Men en anden betydelig faktor var, at avisen »Føringatíðindi« nu var udkommet i nogle år, og det viste sig, at man sagtens kunne skrive om alle mulige ting på færøsk. Og de der skrev i avisen opfattede de indlånte ord som noget fremmed; det afsløres derved at sådanne ord ofte står i citationstegn.

Fra 1889 udkom en almanak fra Københavns Observatorium, og Jakob Jakobsen stod for den færøske udgave. Her fik han rigtig sin sag for, fordi nu skulle han skrive om astronomi og andre fagområder på færøsk, og det var en stor udfordring. Som eksempler på nydannelser fra almanakken kan nævnes: gongustjørna (da. planet), halastjørna (da. komet), lcerdur háskúli (da. universitet), málmerki (da. sprogtræk), sjónarringur (da. horisont), snúningstíð (da. omdrejningstid), sólstøður (da. solhverv), stjørnumerki (da. stjernebillede), stjørnutorn (da. observatorium), tvørmál (da. diameter).

Jakob Jakobsen udgav også en samling færøske middelalderdiplomer »Diplomatarium Færoense« (1907), og skrev en udførlig indledning til den. Derfra kan nævnes disse eksempler på nydannelser: bókasavn (da. bibliotek), málføri (da. dialekt), nasaljóð (da. nasal), sjálvljóð (da. vokal), skjalasavn (da. arkiv), trúarboðari (nu: trúboðari) (da. missionær), trúbótin (da. reformationen), tvíljóð (da. diftong).

Fra et andet af Jakobsens hovedværker »Poul Nolsøe. Lívssøga og irkingar« (1908-12) kan eksempelvis nævnes: eftirspurningur (da. efterspørgsel), einrøða (da. monolog), eygnagløs (næppe brugt, nu snarest: brillur) (da. briller), havnarleiðvísari (ikke brugt) (da. lods), herflotastýri (da. admiralitet), hugsjón (da. ideal), klombrar (nu: klombur) (da. parentes), kollvelting (da. revolution), laknisfrøði (nu: læknafrøði) (da. lægevidenskab), misprenting (da. trykfejl), siðamenning (nu: siðmenning) (da. kultur), siglingarfrøði (da. navigation), skaðatrygging (da. assurance), skráskrift (nu: skákskrift) (da. kursiv), úrdráttur (da. produkt). 
Jakob Jakobsen benytter sig af hovedsagelig to metoder, når han danner nyord: 1) ved oversættelseslån 2) eller ved at udvide betydningsområdet i gamle ord. En betydelig del af Jakobsens nyord er lånt eller i hvert fald inspireret af islandsk, mens oversættelseslånene i almindelighed udgår fra dansk. Her er nogle eksempler: bókamentir (nu: bókmentir) (isl. bókmenntir, da. litteratur), fyrimynd (fyrirmynd, forbillede), halastjørna (halastjarna, fiksstjerne), landbúnaður (landbúnaður, jordbrug), siðamenning (nu: snarest som siðmenning i betydningen 'civilisation' (siðmenning, kultur), siglingarfrøði (siglingafræði, navigation), sjónarmið (synspunkt), hugsjón (ideal), sjónarringur (sjónarhringur, horisont), skynsemi (fornuft), skjalasavn (skjalasafn, arkiv), trúbót (reformation), upphav (begyndelse), varðhald (vagt), yvirlit (yfirlit, oversigt). Andre neologismer er friere af sit forlæg, eksempelvis: miðjarðarringur (miðjarðarbaugur, ækvator), sjónarvitni (sjónarvottur, øjenvidne), skaðatrygging (voðtrygging, assurance), skráskrift (skáletur, kursiv), sóttverja (sóttvørn, karantæne).

En tredie mulighed, som er at tillempe låneordene til færøsk fonotaks eller bøjningsmønster benytter Jakobsen sig ikke af. Senere er denne mulighed blevet rigt anvendt, eksempelvis med følgende ord: bilur (bil), konteynari (nu også almindeligt som: bingja; container), súkkla (cykel), greyp (grape), vesi (wc). Andre er optaget uændret, fx: mikrofon, telefon, faks eller fax, radio.

I tiden efter dr. Jakob Jakobsen er der andre sprogfornyere, bl.a. filologen Christian Matras, botanikeren Rasmus Rasmussen, ornitologen Mikkjal á Ryggi, embedslægen Hans Debes Joensen, geologen Jóannes Rasmussen og lærer Jóhannes av Skarði. De har alle ydet en betydelig indsats på hver sit område og gjorde meget ud af at udvikle og benytte neologismer i det, de skrev, og det er på områder, hvor det færøske skriftsprog ikke i forvejen var specielt dyrket. Jeg vil kort vise et udpluk af nogle af de neologismer, som tilskrives professor Christian Matras, og som for en stor del fremkom i forbindelse med at han — lige som dr. Jakob Jakobsen — oversatte den almanak, som Københavns Observatorium udgav, til færøsk: ráksnúgvin (opportunistisk), mýl (molekyle), evnisbundin (materiel), ígerð (infektion), yrkisgagn ((legems)organ), sannkenning (erkendelse), sjóbúnaður (havbrug), fjølfrøðingur (polyhistor), skilmarking (definition), formliga (formelt), algilding (generalisering).

En anden sprogfornyer bør også nævnes. Professor Jóhan Hendrik W. Poulsen (1934-) har siden 1970-årene udmærket sig som en dygtig og produktiv ordsmed, såvel i almensproget som i fagsproget. Nogle få eksempler skal nævnes her: flogbóltur (volleyball), fløga (CD), gegni (habilitet), hugburður (holdning), samgildur (analog), samleiki (identitet), savnindi (arkivalier), talgildur (digital), telda (computer, dator), tyrla (helikopter). Han har også redigeret fagordlister, bl.a. en computerordliste (1990) og en olieordliste (2002). Den sidste indeholder omkring 1.000 forskellige ord. Orddannelsesprincippet er udelukkende det puristiske: nydannelser på hjemlig grund. Metoden er hovedsagelig sammensætninger (fx: flog-bóltur, hug-burður, tal-gildur) og afledninger (telda). Til dels er gamle ord blevet udstyret med ny betydning (fløga). Det skal siges, at visse af disse ord har vist sig at være yderst anvendelige og produktive i nye sammensætninger, fx telda og fløga, jfr. fx teldubrcev (e-mail), teldufløga (CD-ROM), teldufrøði (datalogi), teldusníkur (hacker), telduspcel (computerspil), fløguspcelari (CD-afspiller), fløgustøð (CD-station).

Som det fremgår er neologismerne produkt af enkeltpersoners arbejder, som har gået ud på at formulere sig på færøsk på et udyrket område for første gang. Det medfører selvfølgelig, at der er visse områder, som er blevet dyrket, mens andre stadig ligger udyrket hen. Som eksempel herpå kan nævnes mange tekniske fag (tømrerfag, maskinfag).

Efter at det Færøske sprognævn blev etableret i 1985 har nævnet spillet en central rolle inden for færøsk sprogrøgt. I sprognævnets formålsparagraf står bl.a., at nævnet skal fungere som sprogrøgts- og sprogværnsorgan og det skal indsamle og registrere nye færøske ord samt være behjælpelig med at udvælge og skabe nye ord. Nævnet skal også være opmærksom på udvikling af fejlagtig sprogbrug og prøve at forhindre, at den fæstner sig. Sprognævnet har lige fra begyndelsen leveret en lang række forslag til neologismer på 
alle mulige fagområder, men også inden for almensproget. Ofte sker dette efter direkte henvendelse fra sprogbrugere som i sin hverdag er i bekneb med et bestemt ord eller en bestemt vending. Et lille og tilfældigt udpluk af sprognævnets forslag skal nævnes her: stoytkoddi (air bag), lívgagnafrøði (anatomi), verklagslóg (anlægslov), fylgiskjal (attachment), hornabóltur (baseball), kagi (browser), stakdømi (case), kjatt/kjatta (chat), avkotari (dekoder), tvíklikkja (dobbeltklikke), fíluflutningur (filoverførsel), verjugarður (firewall), rørskoyti (fittings), framsenda (forward), bikarljós (fyrfadslys), íleguarvur (genetisk arv), dulleiðing (hypnose), kunningarfrøði (informatik), hvøkil (katalysator), einala/einaling (klone/kloning), samkenna (kondolere), cetlanarskriv (letter of intent), frumband (masterband), smáfløga (minidisk), útveita (outsource), fjølskapaður (polymorph), einskilja/einskiljing (privatisere/privatisering), váðagreining (risikoanalyse), samhýsing (samhusning, en. co-location), kurla (snabel-a, @), samværi (symbiose), leitiforrit (søgeprogram), liðmenning/bólkamenning/toymismenning (teambuilding), fjarlæknafrøði (telemedicin), tykissamfelag (virtual community), tykisrúm (virtuelt rum), vevstjóri (webmaster), heimsvevur (World Wide Web), bingja (container), glcera (transparent), uppvørpa (overheader), evstamark (deadline), heila/heiling (heal/healing), samkynd/samkyndur (homoseksualitet/homoseksuel), tvíkilja (katamaran), fyribúnaður, tilbúgving (beredskab), farstøð (terminal).

Ikke overraskende knytter mange af de her nævnte forslag om nyord sig til computere og sager, som relaterer sig til det. For yderligere oplysninger kan jeg henvise til det Færøske sprognævns hjemmeside: www.fmn.fo hvor man kan finde en hel del oplysninger om nævnets virke og bl.a. også finder ordlister, som omfatter fx geologiske, juridiske og datalogiske termer samt en ordliste med terminologi inden for olieindustrien.

Hidtil har jeg mest omtalt det arbejde med at udvikle færøsk ordforråd, som er blevet gjort gennem de sidste godt og vel 100 år. Men der er naturligvis andre faktorer, som har haft afgørende betydning for at befæste og styrke det færøske sprogs position på Færøerne. Jeg skal komme ind på enkelte af disse.

Færøsk blev først tilladt som undervisningssprog på Færøerne i 1938. Førhen havde det kun været et af mange fag på skolernes skema. I 1940 besluttede Lagtinget, at færøsk skulle være undervisningssprog både i folkeskolen og i andre undervisningsinstitutioner på Færøerne. Selv om der i forvejen var udkommet enkelte bøger på færøsk, som var egnet til undervisningsbrug, så gik det langsomt med at få anskaffet færøsksproget undervisningsmateriale til den færøske skole.

Grundlaget til en færøsk skole med færøsk undervisningsmateriale blev for alvor langt med en lov af 1959 om etablering af et færøsk skolebogforlag, som fik pålagt at fremskaffe og udgive undervisningsmateriale til den færøske skole. Det er dog først i 1970-erne, at der rigtig kommer gang i udgivelserne af undervisningsmateriale, og siden har der været gang i udgivelserne. For få år siden var det samlede antal titler, som skolebogforlaget havde udgivet, nået op på omkring 700, og af dem var 540 titler udgivet inden for de seneste 20 år.

Fremskaffelse og udgivelse af undervisningsmateriale på færøsk er unægtelig tæt knyttet til udviklingen af det færøske sprog på mange fagområder. Således har forlaget for ca. 10 år siden udgivet det første færøske atlas. Det er på mange måder et pionærarbejde. Bare det at selve indfaldsvinkelen ud i verden hermed er flyttet fra en dansk indfaldsvinkel til en hjemlig færøsk er noget af en nyskabelse.

Men udgivelsen af Verdensatlaset understregede meget tydelig de problemer, som man til stadighed støder på, når man skal lave undervisningsmateriale på nye og endnu uopdyrkede områder. Det gælder navnlig navnematerialet og sprogformen, hvor ortografien er blevet tillempet færøsk fonotaks og ortografi. I enkelte tilfælde har man oversat fremmede navne og i andre genoptaget gamle norrøne navne, på bekostning af andre almindeligt brugte. Det medførte bl.a. mange højlydte protester. På mange måder kan man sige, at den linie, som er blevet fulgt i atlaset, er en streng puristisk linie, som lægger sig tæt op ad den, som det 
færøske sprognævn stod for på det tidspunkt. Eksempler på navnestoffet i atlaset er følgende: a) tillempelse til færøsk fonotaks og ortografi: Brúsell (Bruxelles), Kili (Chile), Liktinstein (Lichtenstein), Simbabvi (Zimbabwe), Sveis (Schweiz), Teiland (Thailand) b) gamle historiske navne genoptaget: Bjørgvin (Bergen), Borgundarhólmur (Bornholm), Sikiloy (Sicilia) og c) »oversættelser«: Góðvónarhøvdi (Cap det gode Håb), Høvdastaður (Cape Town).

Det at en så stor del af al færøsksproget faglitteratur udkommer i det færøske skolebogforlags regi medfører også, at der er sket en vis institutionalisering og formalisering af færøske neologismer. Og det er også et faktum, at der har været og er et tæt samarbejde mellem forlaget og det færøske sprognævn, bl.a. når det gælder færøsk terminologi.

Generelt er udgivelse af bøger en betydelig faktor, når det gælder styrkelsen af et sprogs position i samfundet. Det ligger i sagens natur, at det færøske bogmarket er begrænset, men på trods af det udgives der forholdsvis mange bøger på Færøerne. Siden den første bog udkom i 1822 og til slutningen af år 2000 var der udkommet ialt 4.051 forskellige titler på færøsk. Langt den største del af disse titler er udkommet inden for de sidste 50 år. År 2000 var faktisk rekordår når det gælder bogudgivelser på Færøerne. Det år udkom der 169 bøger på færøsk. Af dem kan 32 bøger klassificeres som fiktion, dvs. det omfatter romaner, noveller, poesi og skuespil. Faktisk var 11 af disse 32 titler digtsamlinger. Faglitteratur, dvs. fx teknisk eller videnskabelig litteratur og undervisningsbøger stod for 100 titler, hvoraf langt den største del var oprindelig skrevet på færøsk. Samme år 2000 blev der udgivet 37 bøger for børn og unge, men her var de fleste oversættelser. Årbøger, rapporter og den slags publiceret i bogform er ikke inkluderet i det samlede antal titler på 169 for året 2000. Måske er dette antal ikke meget totalt set, men er dog relativt stort når man betænker en befolkning på 47.000 mennesker. En tommelfingerregel siger, at en færøsk bog normalt trykkes i 1.000 eksemplarer.

En institution, som må siges at have haft en enorm betydning for styrkelsen af det færøske sprog på Færøerne og har været med til at befæste dets position i befolkningens bevidsthed er Den færøske radio. Den blev etableret i 1957 og har lige fra begyndelsen udelukkende haft udsendelser på færøsk. Radioen har også mere eller mindre bevidst spillet en betydelig rolle som forbillede når det gælder et røgtet sprogbrug og har været med til at lancere nyord i den brede befolkning. Tv kom relativt sent til Færøerne; det offentlige Færøske tv blev først etableret i 1984. Den har ikke i lige så høj grad som radioen haft succes med at have sine udsendelser på færøsk, selv om der naturligvis findes regelmæssige færøsksprogede programmer, bl.a. nyhedsudsendelser og aktualitetsprogrammer. I langt længere perioder end både radio og tv har de færøske aviser spillet en stor og vigtig rolle som bærere af færøsk sprog og har været med til at udvikle det til et moderne kultursprog.

Men et samfund som det færøske er under konstant påvirkning udefra, og det er for en stor del ikke nødvendigvis noget negativt, men man skal ikke være blind for, at det sprogligt set sætter enorme krav til alle og enhver om at gøre sin indsats for at bevare sproget, og det gøres bedst ved at bruge og udvikle det på alle mulige områder.

Hvis vi vender tilbage til nyordspolitikken, så viser det sig — firkantet sagt — at neologismerne for det meste lever og fungerer i skriftsproget og faktisk dominerer der, mens de ord, som neologismerne er tiltænkt at afløse, for en stor del lever videre i talesproget og forekommer lige så hyppigt der som neologismerne.

En del af neologismerne, som fremkommer, bliver lanceret i et sprogbrev, som det færøske sprognævn med jævne mellemrum udsender offentligt. Inden for de sidste år har sprognævnet også fået en ret så velfungerende hjemmeside, hvor nyt materiale af denne art, også bliver lagt ud. Andre neologismer bliver lanceret gennem den færøske radio, det færøske tv eller gennem aviserne. Det lader til at være en effektiv måde at lancere ordene på. Mange er skeptiske i begyndelen, men efterhånden viser det sig, at mange af ordene bliver en naturlig integreret del af sproget. 
Med hensyn til dannelse af nyord i færøsk er der ingen tvivl om, at færøsk traditionelt har lagt sig meget tæt op ad den linie, som man har fulgt i islandsk sprogrøgt, og at mange færøske nyord har et klart islandsk forbillede.

Det som kendetegner færøsk sprognormering i dag er purismen, som er en type ideologisk ordforrådsnormering, som er nationalt baseret. Begrebet sproglig purisme indebærer, at man prøver på at holde sproget rent for visse typer ord, som kommer eller er kommet ind i sproget udefra, dvs. at pointen med purismen er at værne sproget mod uønsket sprogkontakt.

Spørgsmålet omkring ordforrådet er til stadighed til diskussion i det færøske sprogsamfund. Især foregår der jævnlig diskussion om, hvad der er god og slet sprogbrug.

Hovedsynspunkterne repræsenterer typisk et puristisk sprogsyn som ønsker at begrænse mængden af fremmed ordstof på den ene side og et mere liberalt sprogsyn som er åbent for importord på den anden side. Der findes naturligvis kritiske røster i debatten, som synes at sprogrøgten har slået ind på en for stræng og begrænsende linie og at man generelt har været for bange for at acceptere fremmede ord (og det vil traditionelt sige danske ord, men nu også engelske) som en naturlig del af færøsk.

Naturligvis fungerer det ikke på den måde, at alle forslag om færøske afløsningsord for et fremmed ord eller term per automatik accepteres af sprogsamfundet. Det har man aldrig nogen sikkerhed for, og der findes talrige eksempler på neologismer, som helt enkelt aldrig har vundet indpas i sproget af en eller anden grund. I så henseende udviser sprogsamfundet en sund kritisk sans. Eksempelvis har man lykkes at udskifte det danske telegram med det mere færøsk klingende fjarrit, mens det aldrig har lykkes at erstatte telefon med fx fjarrøðil eller máltráður. Alle anvender ordet telefon. Men så kan man også se, at det ord danner grundlag for yderligere en neologisme, og det er ordet fartelefon for mobiltelefon.

I praksis fungerer det ofte sådan, at vi har to paralelle ord om det samme, et mere fremmedartet ord, som er hyppigt i talesproget og i mere uformelle sammenhænge, mens skriftsproget og det mere formelle sprog hælder til at anvende et færøsk afløsningsord. Som eksempler på det kan nævnes konteynari vs. bingja og e-mail/e-meyl vs. teldupostur. Samme forhold er der mellem mobiltelefon vs. fartelefon.

Det at færøsk har levet og stadig lever så tæt op ad dansk er ikke noget enestående eksempel. Sprogkontakt har der været til alle tider. I vikingetiden havde fx det norrøne sprog stor påvirkning på engelsk og op gennem middelalderen var det tyske sprogs påvirkning på de nordiske sprog ret stor og udbredt, og i dag taler man meget om det engelske sprogs dominans overalt i verden. Disse kendsgerninger sætter naturligvis store krav til ikke mindst små sprogsamfund som det færøske, især fordi effektiviteten i denne sprogpåvirkning er blevet så stor i takt med den rivende teknologiske udvikling, som vi er vidne til i disse år. Vi behøver blot at nævne fænomener som internet og satelit-tv. Derfor sker påvirkningen med langt større hastighed og er mere dybtgående end den har været førhen.

Det som vi med god grund kan frygte er den tendens, at flere og flere fagområder overgår til udelukkende at benytte sig af engelsk som arbejdssprog. Det er ikke noget isoleret færøsk fænomen, men gælder også langt større sprogsamfund. Jeg har fx hørt, at i Tyskland overgår alt flere tidsskrifter til udelukkende at publicere artikler på engelsk, fordi forskerne naturligvis vil nå så langt ud i verden som muligt og at de ikke anser tysk for at være et stort nok sprog til det formål!

I en færøsk sammenhæng er situationen den, at vi efterhånden har påvirkning på to fronter at forholde os til: fra dansk og fra engelsk. Den populære kultur er meget påvirket af dansk: en stor del af tv-programmerne som vises på Færøerne (også i Færøsk tv) er danske eller er bearbejdet til danske seere ( $f x$ med danske undertekster), hver uge kommer der tonsvis af danske ugeblade til landet, triviallitteratur læses på dansk, computerprogrammer findes i danske versioner o.s.v. Det her er naturligvis befordrende for færingers kompetence i 
dansk, men tager unægtelig noget fra den færøske. Det engelske trænger sig på først og fremmest i diverse tv-kanaler, i ungdomskulturen (inden for musik, computerspil, film o.s.v.), via internet, men også i den mere akademiske del af kulturen, fx i forbindelse med internationale konferencer og i videnskabelige tidsskrifter. På Færøerne har vi i over 50 år haft et videnskabeligt tidsskrift, Fróðskaparrit, som helt fra begyndelsen så en ære i at publicere alle artikler på færøsk og på den måde var med til at udvikle færøsk som videnskabssprog. Men inden for de seneste år er en markant ændring sket, idet alt flere artikler nu publiceres på engelsk og tilsvarende færre på færøsk. Færøske videnskabsmænd og — kvinder vil også gerne ud i verden!

Afslutningsvis og med henblik på fremtidsudsigterne for færøsk vil jeg gerne sige, at i udgangspunktet ser det færøske sprogs fremtid dog fortrøstningsfuld ud: færinger lader til at være glade for sit sprog og indstillet på at bruge det i alle livets aspekter, men samtidig bør vi ikke være blinde for at det kræver hårdt arbejde at opretholde et kultursprog nu om dage. Al udvikling sker i rivende fart og det kræver mange resourcer, menneskeligt og økonomisk, at følge trop. Derfor er det vigtigt at politikere og andre bevilgende myndigheder indser disse behov og ikke udelukkende opfatter bevarelsen og udviklingen af sproget som noget naturgivet, fordi det er det ikke i et moderne massekommunikationssamfund.

(C) Zakaris Svabo Hansen

\section{Referencer}

Føroyska málnevndin. Tórshavn: www.fmn.fo

Hansen, Zakaris Svabo (1996): »Faroese now and in the future«. In: Tidsskrift FOVU Dialog i nordisk folkbildning och vuxenundervisning 1.

Hansen, Zakaris Svabo (2001): »Faroese — a diachronic and synchronic overview «. In: Minor Languages of Europe. A Series of Lectures at the University of Bremen, April-July 2000. Edited by Thomas Stolz. Universitätsverlag Dr. N. Brockmeyer: pp. 123-141.

Hansen, Zakaris Svabo, Jacobsen, Jógvan í Lon and Weyhe, Eivind (2003): »Faroese«. In: Germanic Standardizations. Past to Present. Edited by Ana Deumert and Wim Vandenbussche. John Benjamins Publishing Company, Amsterdam/Philadelphia: pp. 157191.

Jacobsen, Jógvan í Lon (2001a): »Standardfærøsk eller standard i færøsk«. In: Sprog i Norden 2001: s. 47-65.

Jacobsen, Jógvan í Lon, Hansen, Zakaris Svabo, Johansen, Anfinnur, Staksberg, Marius and Petersen, Hjalmar P. (2001b): »Udredning om domænetab og sprogpolitiske initiativer i færøsk «. http://www3.siu.no/vev.nsf/info/Internasjonalisering-NordmalForum2001$\underline{\mathrm{E} 4 \mathrm{BB} 6}$

Jakobsen, Jakob (1957): Greinir og ritgerðir. Tórshavn.

Larsen, Kaj (1993): »Hin fyrsti málreinsarin«. In: Málting 9, 1993: 12-19. 